The Geneva Papers on Risk and Insurance, 20 (No. 77, October 1995) 423-429

\title{
Insurance as a Product of National Values*
}

\author{
by Geert Hofstede **
}

\begin{abstract}
Summary
An insurance is an immaterial product that is valued subjectively by its recipients. The way this is done depends on the values that dominate in a certain society, values that have come into being through the years. In this article the dominant values of the Netherlands and of a number of other relevant countries are being compared and are being linked with national insurance systems. Three important values are solidarity, independence and predictability. Because of the influence national values exert, there are limits to the extent to which insurance systems can be imported and exported. This obviously has consequences for the role of the European Union.
\end{abstract}

\section{Insurance: culture-sensitive products}

An insurance is an immaterial product that is valued subjectively by its recipients. What people buy is a "feeling", a sense of security. Because of the subjectivity involved, the need for and the appreciation of insurance products differ from one person to another. On top of this personal need and appreciation, there are collective differences between categories of people, such as between people that follow specific professions. And in addition to these, there are also collective differences between countries.

Differences in the way distinct countries subjectively value insurance products have not come into being by chance. They have evolved out of historically developed differences in values between one national society and another. Patterns of appreciation are part of the culture of a society.

Culture in this sense includes more than the field the Ministries of Cultural Affairs are active in. These ministries deal with culture in the narrower sense, culture as a synonym for "civilization". Culture as it is relevant to the insurance market, however, is the word social anthropologists use: it has a much broader sense. One of the possible definitions of culture

* A contribution to the international conference on "Uninsurability: who carries the risk?", held on 16 February 1995, Amsterdam, organized by the Verbond van Verzekeraans, Den Haag. The following three papers were also presented at this conference.

** Professor Dr. Geert Hofstede, Institute for Research on Intercultural Cooperation (IRIC), University of Maastricht and Tilburg, the Netherlands. 
in this broader sense is "the collective mental preprogramming that distinguishes the members of one group or category of people from another". The differences in culture in this sense between countries are intuitively evident. Any child knows that the Dutch differ from the Germans, the English from the French and the Japanese from the Americans. But what a child is expected to know are often unacceptable stereotypes. Within any country one human being differs enormously from another. Real cultural differences between countries do exist, but they are statistical phenomena that can only be described soundly by way of research, e.g. through surveys.

Demonstrable cultural differences between countries are rooted in the history of each separate country. They are to a lesser or greater extent reflected in the institutions (government, family, church, organizations, laws) of the countries involved and in the ideas that become popular in a country. The institutions in their turn contribute to preserving the culture they have originated from. It is for this reason that cultures and cultural differences have been remarkably stable through the ages. Comments made by travellers from country A about country B may appear very relevant hundreds of years from date. Two centuries ago a French visitor to the Low Countries called the Dutch "a jealous people who are irresistibly attracted by everything that is dull ". Some French feel the same today; whatever may have changed in the Dutch and in the French, the difference has remained stable.

As we know, the institutional context of the various types of insurances differs quite strongly, even within Western Europe. These institutional differences cannot, however, be directly gathered from the national cultures. That would be too simple. Institutions have also been influenced by historical coincidence and international developments. But the national cultures do influence the specific way in which people in a country react to international developments. In short: national cultures constitute one of the elements on which differences in institutions are based. The national cultures draw the lines between what is and what is not possible in a country. When after the second World War the British occupying force decided to bring into operation their own Beveridge system of social security in Germany, the German employers and employees alike offered resistance and the plan was not carried out.

\section{International changes in insurance patterns}

Of course the system of insurances is under discussion not only in the Netherlands. Changes in the world affect many if not all countries. One should think of changes like globalization of markets, the opening of frontiers as a result of which e.g. advantageous risks may leak to foreign countries, supranational guidelines, ageing populations, an increasing number of single-parent-families, changes in the environment, technological changes with unknown long-term risks such as e.g. genetic manipulation.

Changes like these are the challenge national insurance systems are being confronted with. The ways in which people react to such changes differ from one country to another, just like they did in the past. And in the different reactions culturally determined values play a key part. Insurers have to do with culture, whether they like it or not. Those that make the decisions are themselves children of their national culture, too.

\footnotetext{
${ }^{1}$ Quoted in Duke de Baena, The Dutch Puzzle, The Hague: Boucher, 1968, p. 65.
} 
Three sets of values which have been shown to differ from one country to another play a part in the development of insurance systems. The first is solidarity and that which goes with it, the second is independence and the third is predictability. I shall proceed to discuss them one after the other. For the first two, I shall try and work out what the effects of different choices in values will be in terms of social security, catastrophes and liability.

\subsection{Solidarity as a national culture trait}

The direction one wants social security to move in has a lot to do with the degree to which a country has traditionally valued solidarity. It is important in this context to differentiate between solidarity with one's own group and solidarity with everybody. What this means is explained to us in the Bible in the parable of the good Samaritan. This parable holds that it is only normal that a Jew should show solidarity with another Jew; what is special here is that solidarity is shown by a Samaritan, an outsider. The solidarity I shall refer to below is the one of the good Samaritan.

Within the Western world there is an obvious value conflict with respect to the criteria for the distribution of wealth. The opposites are achievement and solidarity. ${ }^{2}$ In countries like the United States, Great Britain and the other Anglo countries Australia, Canada and New Zealand, achievement is highly valued. If you won't work, you shan't eat. Those that cannot work, or that cannot work any longer, have a bad time. In countries like the Netherlands, Denmark, Finland, Norway and Sweden, solidarity is highly valued. Society is responsible for all its members, especially those who are weak and unable to help themselves. According to my research, the other European countries Austria, Italy, Switzerland and Germany rather value achievement whereas Belgium, France and Spain take a middle position.

It is important to realize that these differences in values are very deeply ingrained. It may well be that you have associated them with the right-left contrast in national politics. But even the political right in the Netherlands and Sweden is in favour of a measure of solidarity which e.g. in the United States would be held to be extremely left-wing. The United States and Great Britain are rich countries but at the same time they know poverty, e.g. among elderly people. By Dutch standards this is both shameful and unnecessary. Whatever solidarity is still left in the Anglo countries, with every election it is contested; we have recently seen this happen in the United States and we have seen it in Thatcher's Great Britain. At the moment, "welfare state" is a dirty concept in the U.S.. By now the scale may well have tipped: a backlash is only to be expected and in a few years' time there could very well be another "New Deal". In countries like the Netherlands and Sweden solidarity as such is hardly ever under discussion; what people negotiate is the degree to which it is practically and economically possible to meet the requirements of solidarity.

In countries in which solidarity is highly valued, social security is founded on redistribution in a national insurance. This is called subsidizing solidarity, as opposed to hazard solidarity in groups that share certain risks among themselves. Hazard solidarity suits a society that values achievement.

2 The dimension of national cultures that is relevant here is Masculinity (achievement) versus Feminity (solidarity). See G. Hofstede, Cultures and Organizations: Software of the Mind, London: McGraw-Hill, 1991, p. 96 ff. 
In countries that greatly value solidarity, insurance against catastrophes in the end are a responsibility of the government. If a private insurance pays for the damage: so much the better. But if private insurances fail, it is unthinkable that the government would ever let victims down. Essentially there is no limit to the responsibility of the state. In countries that set great store by achievement, there $i s$ a limit determined by reinsurances and it is set by business interests.

In a country where solidarity is treasured, the community feels responsible for victims; one will not easily try to hold a legally liable party responsible. In this context, however, the value of independence plays an even larger role. I shall turn to that now.

\subsection{Independence as a national culture trait}

The degree to which adults are expected to go their own way varies greatly from one national culture to another. Cultures differ on a dimension that runs from individualism to collectivism. ${ }^{3}$ Individualism pertains to societies in which the ties between individuals are loose: everyone is expected to look after himself of herself and if necessary after his or her own family. Collectivism pertains to societies in which people from birth onwards are integrated into strong, cohesive groups which in exchange for unconditional loyalty protect them as long as they live.

It is historically demonstrable that increasing wealth in a country makes its culture move towards the individualism pole. This does not imply, however, that all wealthy countries have become equally individualistic. My own research, which, incidentally, was repeated by others, showed the United States, Great Britain and the other Anglo countries and the Netherlands to be most individualistic. Sweden, France, Norway, Switzerland, Germany and Austria are wealthy, it is true, but they turned out to be less extreme in their individualism than the former group. Italy, Belgium and Denmark stand midway between these two groups.

Privatization of tasks that formerly were handled by the state has more appeal to highly individualistic cultures than to those that are less individualistic. These days, privatization is the fashion, internationally. Whether the nature of a specific task makes it fit for performance by society or rather by a market party that seeks to make profit is a question which I feel is not always considered carefully enough. At times the rather naive idea that activities that have been privatized will not cost the state anything at all plays a part here as well. But that, obviously, remains to be seen; it may well be true that a state that wishes to use services that have been privatized ends up paying more rather than less. Privatization is not a panacea. If the scales continue to tip towards privatization, the coming years will inevitably show a reaction.

In societies that are highly individualistic, the state cannot demand a lot from its citizens. In societies that are less individualistic, this can be done and what we see there is e.g. that social services go hand in hand with imperative demands on the recipients: they may be forced to accept available jobs. In countries like Sweden and Norway, that are less individualistic than e.g. the Dutch are, the state often acts as a mediator on the labour market. In the Netherlands, however, those that are entitled to unemployment benefits are being kept away from the labour market; macroeconomic measures are put to use to fight

\footnotetext{
${ }^{3}$ See Hofstede, Cultures and Organizations, p. $49 \mathrm{ff}$.
} 
unemployment. Even the idea that students should perform reasonably well at school or the university before they can count on a study grant is a controversial point in the Netherlands. Foreigners find it hard to understand that.

The individualistic citizen is a calculating citizen. After all, the principle underlying the free market is that parties are guided by what they suppose to be their own interests. In individualistic societies it is only to be expected that citizens calculate. In countries that are less individualistic, citizens are more easily led by non-economic group norms.

With respect to natural disasters, countries that are less individualistic will consider a mutual insurance more readily than countries that score high on individualism. The ancient principle behind sharing risk is, in essence, a collectivist principle. It has been said that the word "average" stems from the Dutch word averij: damage. In highly individualistic societies, one would expect to find the insurer-entrepreneur trading risks. The concept of compulsory insurances is more readily accepted in cultures that are not all that individualistic.

If someone has suffered badly owing to the actions of an individual or a legal body, this individual person or legal body is more likely to be held responsible in an individualistic society than in a collectivist one. Above I have already pointed out that there is a negative correlation between legal liability and the degree to which solidarity is valued favourably. Especially in the United States we find a combination of weak solidarity and strong individualism and we all know the excesses this can lead to when it comes to legal liability; apart from the achievement mentality, factors that contribute are the large numbers of lawyers bent on making a profit - they work on commission - and an administration of justice that is entrusted to lay juries. As far as Europe is concerned, Great Britain has a value pattern which resembles to that of the United States and although the number of claims being lodged as well as the amounts being claimed do not reach U.S. levels, nowhere in Europe more disputes on liability are taken to court than in Great Britain. As the other European countries have both different legal systems and different values, they will not follow the example Great Britain sets. The Dutch culture may be highly individualistic, it also seeks solidarity. Both characteristics are recognizable in the way the Dutch judiciary works and in the Bar. In comparison with other countries, the Netherlands has a large number of disputes that is being settled out of court. Fairness for both parties is the norm. It is unlikely that such a system will ever see claims being paid that reach U.S. levels.

\subsection{The need for predictability as a national culture trait}

National cultures differ demonstrably in their need for predictability. Elsewhere I have called this need "uncertainty avoidance". ${ }^{4}$ This is not the same as avoidance of risk. Risk is the raw material of the world of insurance. A risk is something one can estimate. As soon as that cannot be done any longer, risk changes into uncertainty. The resulting uncertainty calls forth anxiety and in some cultures this anxiety is greater than in others. Where anxiety is great, a culture creates institutions which, it hopes, will guarantee predictability.

According to my research, the need for predictability is relatively great in Belgium, France, Spain, Italy, Austria, Germany and Switzerland; it is relatively small in Sweden, Denmark and the Anglo countries; the Netherlands and Norway occupy a position midway. In cultures where the need for predictability is strong, the concept of the state is important

\footnotetext{
${ }^{4}$ See Hofstede, Cultures and Organizations, p. $109 \mathrm{ff}$.
} 
and the citizcns feel relatively incompetent with respect to the state. Here the state will supervise the social insurances as a minimum of social security is a prerequisite for an orderly society. In cultures where the need for predictability is weaker, the state rather interferes less. The Dutch steer a middle course as they traditionally have settled affairs in tripartite talks (state, employers and employees).

It is important to differentiate between the predictability norm, the solidarity norm and the independence norm. Whatever happens in a country is influenced by these three norms together. Similar regulations may have quite different causes. If the German and Dutch social security systems are both labelled Rhenish, this obscures the fact that the German system is really based on a need for predictability, it aims at defending the rights of the employees against unpredictable events through what has been called hazard solidarity whereas the Dutch system in fact is based on a subsidizing solidarity that aims to defend weak people in an individualistic society.

\section{The Dutch situation}

So far we have seen that, at any rate partially, insurance systems are products of national values. As far as the Netherlands is concerned these values are (1) a great amount of solidarity with weak people which results in social insurances through which the strong subsidize the weak; (2) independence for the individual which implies that recipients do not face imperative demand; and (3) a minimum of predictability which means that the state has a finger in the pie while at the same time it likes to involve both employers and employees. It is this combination of values that characterizes the Netherlands. The other countries in the European Union have their own value patterns which partly resemble the Dutch pattern and partly differ from it.

It is a historical fact that the Netherlands has not been a forerunner where social security is concerned: until 1950 it had hardly anything worth mentioning. Yet it has struck foreign visitors for centuries that the Dutch take good care of their weak fellow-countrymen. In 1792, for instance, a German remarked that it was customary for gentlemen in the Netherlands to present their domestic personnel with a provision for old age. ${ }^{5}$ In 1873 the Italian De Amicis wrote that "in charity [the Dutch] surpass all nations in Europe 6 ". My mother taught me a rhyme which must date back at least one century and which reads "Holland, Oh Holland, it is a good place, there villains are being fed milk and eggs".

Probably the Netherlands has been able to do without a social security system for a long time because it had relatively little problem finding solutions for individual needs. The country got into greater problems, however, when it started to face structural needs such as those resulting from the economic crisis in the thirties. Conflicting interests had to be bridged through series of compromises in a political system that was highly segregated. It takes a lot of time to reach such compromises and it does not allow for great visions. Even after 1950 things have not always gone smoothly. To mention only one example from the history of Dutch insurance: it took years of struggle before the country had statutory regulations concerning the transferability of pension rights.

\footnotetext{
5 "Twelve cases of foreigners perceiving the Dutch", Den Haag: Institute for Training in Intercultural Management (ITIM), n.d.

${ }^{6}$ Edmondo de Amicis, Nederland en zijn bewoners, Utrecht: Veen, 1985 (1876), p. 140.
} 
Furthermore, the Netherlands has, in comparison with other countries, a very open economy and has of old been responsive to foreign influence and ideas. That does not mean, howcver, that the Dutch can adopt no matter which foreign system. Deeply ingrained national values prohibit this.

\section{Convergence and divergence of cultures and systems}

This brings me to an obvious question. Should we, either within the European Union or within the entire Western world, reckon with either (1) a convergence of cultures and the valucs that go with them or, at any rate, with (2) a convergence of insurance systems?

Is it not inevitable that the intensification of international communication we have witnessed in the fifty years that lie behind us leads to a convergence of national cultures? So far, we have seen little evidence of such a convergence. It may be true that citizens in all sorts of countries watch the same American television programmes, but the emotions they havc while doing so differ considerably and their behaviour has not changed noticeably. The Belgians and the Dutch have been neighbours for 2,000 years now, but the differences in their cultures are still enormous. Intensification of communication may even lead to a divergence of cultures, as it strengthens each separate country in its national identity.

If there is a convergence of cultures, it is likely to affect superficial aspects such as the food and entertainment rather than fundamental values. Perhaps some convergence of values will be observable in some fifty or one hundred years' time. For the time being it is safer, I feel, to assume that the Western world will be multicultural. The differences in solidarity, independence and predictability I have discussed above are here to stay for quite a long time.

Is it not possible, if only within the European Union, to work towards one insurance system, in spite of all the differences in values? Do you still remember the Maastricht Treaty which in December 1991 could only be saved by excluding Great Britain from the social paragraph? The British culture, if you care to believe me, differs from the other cultures in the Union in that it combines limited solidarity with both a strong independence for each individual and a modest need for predictability. No social paragraph whatsoever would have suited the British.

In the field of social security, disaster insurances and legal liability, a compromise that all countries find acceptable is still very far away. What would be acceptable is "a greatest common divisor" which at the same time would not satisfy anybody. Recently it has been suggested in the Dutch press that Europe had better copy the liberal (i.e. British-American) system of social services as, so the argument goes, it is the only system that is affordable with an ageing population. It seems to me that that is the perspective of myopic economists who forget that a society consists of people. I furthermore doubt whether they have any personal experience with the social situation in the United States and Great Britain. Most Europeans feel that these countries do not set an example they are eager to follow.

If only half of my analysis of the role cultural values play is true, Europe will not see standardization of its social security according to the Anglo model. It is much more likely that the European governors will maintain an Europe des Patries in which systems continue to be based on divergent national values and in which only the worst controversies will be eliminated. 